\title{
DIGITAL HERITAGE DOCUMENTATION OF MODERN ARCHITECTURE IN CUENCA - ECUADOR
}

\author{
P. Preti ${ }^{1 *}$, K. Tituana ${ }^{1}$, J. Carvallo ${ }^{1}$, V. Heras ${ }^{2}$, \\ ${ }^{1}$ Universidad de Cuenca, Facultad de Arquitectura y Urbanismo, Cuenca, Ecuador - (paola.preti, \\ karina.tituana,juan.carvallo)@ucuenca.edu.ec \\ ${ }^{2}$ Universidad del Azuay, Facultad de Diseño, Arquitectura y Arte, Cuenca, Ecuador - vheras@uazuay.edu.ec
}

\section{Commission II, WG II/8}

KEY WORDS: 3D Documentation, Recording techniques, Modern Architecture, Laser scanning, Photogrammetry, Built heritage

\begin{abstract}
:
In the city of Cuenca in the south of Ecuador, analogous documentation techniques continue to be the unique registration mechanism for built heritage. The heritage characteristics of modern architecture in Cuenca are not well known, therefore the documentation activities are still based on paper fiches that gather basic data, without the possibility to update or monitor those records. In addition, this type of heritage, is underestimated, not disseminated and devalued by public institutions, owners and by local citizens, who do not find heritage attributes in these buildings. Consequently, this research used technological documentation techniques and tools for the identification, conservation and safeguarding of modern heritage in the city of Cuenca, aiming to raise awareness about modern heritage.
\end{abstract}

With the evaluation of the existing records, this research aspires to validate the digital documentation tools for modern architecture as a first step to its recognition and valorization. Thus, scanner laser, photogrammetry and rectified photography, were used and compared to verify the adaptability of the documentation fields content to modern architecture and the opportunities that the results grants to promote its preservation and management over time.

\section{INTRODUCTION}

\subsection{Modern architecture in Cuenca}

he heritage conservation conscience in the city of Cuenca dates from 1970 (Heras, 2009) when the first building inventory was promoted by the Casa de la Cultura Ecuatoriana (House of the Ecuadorian Culture). In 1982, the historic city center was included in the National Heritage List, and in 1999 due to the exceptional existing values, the historic center of Santa Ana de los Rios de Cuenca was incorporated in the World Heritage List by the UNESCO. Since then, public Institutions such as the Instituto Nacional de Patrimonio -INPC- (National Heritage Institute) and the local Municipality have been trying to adopt measures to preserve and put in value the city's cultural heritage. In line with these actions, the INPC in 2012 started to work in a new heritage inventory of buildings in the buffer zones. As part of the results, the city zone called "El Ejido" was included as part of the city's cultural heritage. A basic fiche was developed for the registration of modern buildings in Cuenca. Nevertheless, the valuable and particular characteristics of this type of heritage are not entirely well recognized due to the lack of knowledge of local modern features. In concordance to Muñoz A. (2009), in Cuenca, there is still a fascination for the past and related styles that prevents looking towards the future and do not give the possibility to recognize local modern architecture.

Consequently, this research established a documentation methodology for modern architecture. A documentation fiche for local modern architecture and a selection of suitable documentation tools has been established. Thus, in the following paragraphs, the selection of a case study will be explained.

\subsection{Case study: The "Peña" house}

For the case study determination, the construction date constituted a fundamental factor. In Ecuador and mainly in Cuenca, the most representative decade of the implementation of architecture with modern characteristics is defined between 1950 and 1960, therefore; buildings built between these periods can be defined as research objects. Another aspect that was considered in the case study selection was the location of the building (see fig. 1). In the buffer zones of the historic city center, that includes "El Ejido", around 200 buildings were inventoried as "modern republican architecture" (INPC, 2017). The final selection criteria of the case study were the access facilities for the registration fieldwork. The residence "Casa Peña", figure 2, fulfilled all the described requirements.

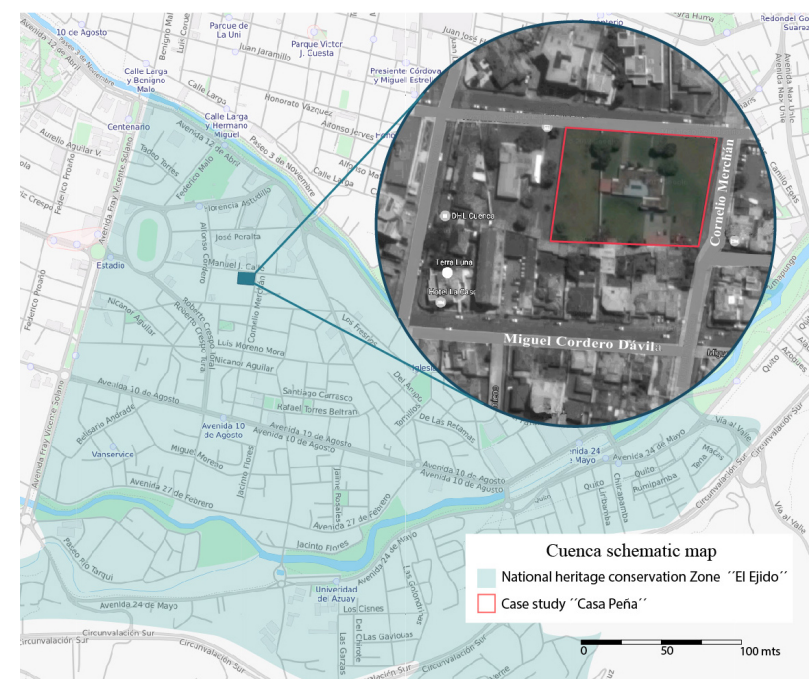

\footnotetext{
* Corresponding author
} 
Figure 1. Case study location in "El Ejido"buffer zone.

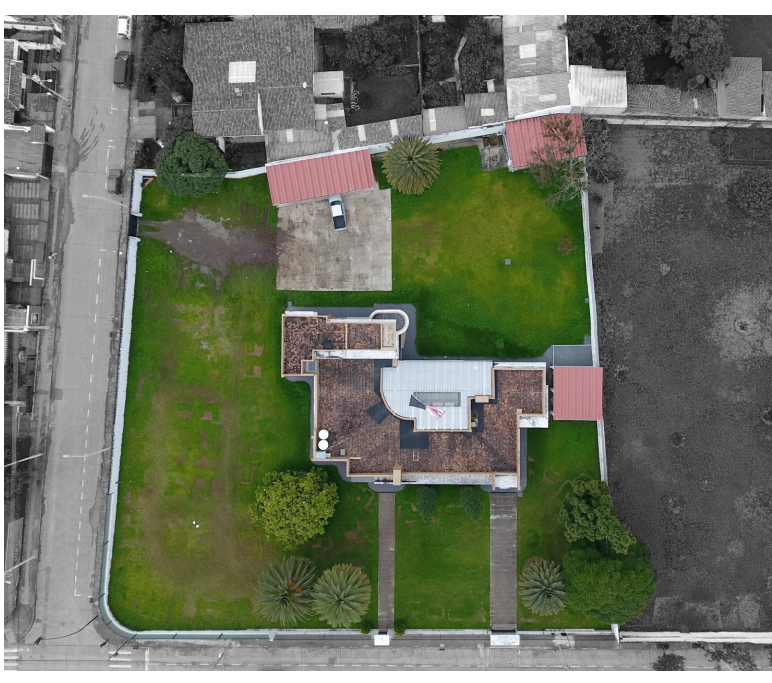

Figure 2. Aerial picture from the case study "Casa Peña"

\section{METHODOLOGY}

\section{Documentation tools for local modern architecture}

After the analysis of the existing documentation methodologies developed for modern architecture by DOCOMOMO, INPC and the Modern Project: Research Guidelines (Gastón \& Rovira, 2007), the main and basic data to document modern architecture was identified. This data was structured into a documentation fiche for local modern architecture in Cuenca that was framed according to ICOMOS (1996), in which the greatest amount of information must be collected for the conservation and preservation of a heritage asset in terms of its functional, formal, historical, technical, constructive and cultural aspects. Figure 3 illustrates the used methodology for this research. Thus a tree step sequence is established to 1) Measure the valuable characteristics that local modern architecture owns, then a 2) Selection of essential data is established. An introduction (case study presentation) is important to contextualize the selected building. Then, a registration fiche facilitates data collection from the author's personal files, sketches, critical texts, budgets and, if possible, a direct approach to the building. These data are necessary for future analysis such as the aesthetic, function, evolution and building transformation. However, the gathered data must be filtered and chosen according to the valorization of modern architecture, since "a large amount of documentation does not ensure, on its own, an adequate assessment of the project and may even be unfavorable" (Gastón and Rovira, 2007, p.20).

Once the data that had to be collected was established, digital documentation techniques were studied to be applied to the graphics information collection phase. The digital measurement tools were selected taking into account the quality and accuracy of the information that can be obtained. These tools allow to automate the process since two-dimensional and three-dimensional graphical information can be obtained that can be used in different ways for future analysis.
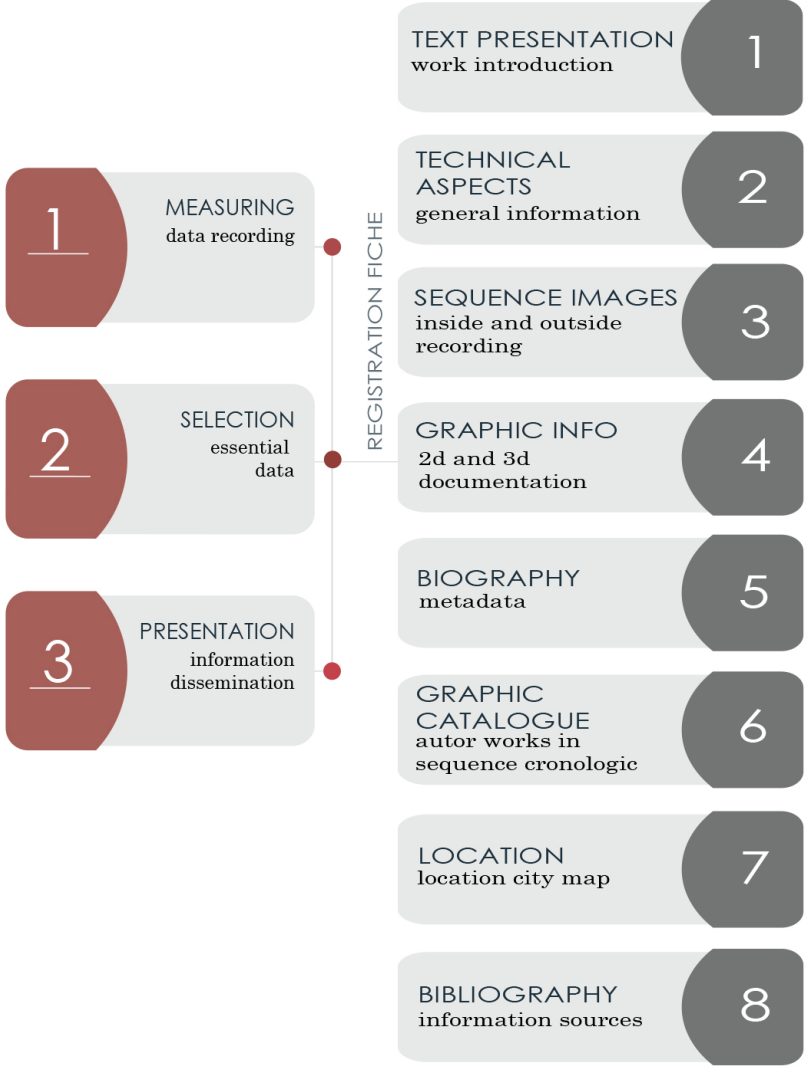

Recording digital process

Documentation process for modern architecture

Figure 3: Heritage documentation methodology developed for the identification of local modern architecture in Cuenca.

The documentation process is carried out by means of measurement, selection, and presentation, which in this study have been determined the phase of data collection, post-production and finally the extraction of results. With the previously detailed criteria, the digital tools selected and used for this research were the laser scanner, photogrammetry, and rectified photography. It is also important to mention that the selection of heritage documentation tools was done in relation to the 3) Presentation and future data dissemination.

\subsection{Recording techniques}

\subsubsection{Laser Scanner}

The data collection was carried out using a Faro Focus laser scanner, which includes a camera, GPS and leveling system, complemented by spheres and grid cards as the targets. The process is carried out in a previously planned circuit that placed the targets at $15 \mathrm{~m}$ of distance, placing between them 3 reference objectives. As it is well known the targets were visible for the coming scanning point as it can be seen in figure 4 .

The point cloud resolution was an important aspect to be determined during the field work. It was related to the later unification of different point clouds.

In the post-production process, the Scene Faro program was used, through which a sequence of steps is taken to obtain the point cloud, the permissible error obtained is less than $20 \mathrm{~mm}$ to be optimal. From this, multiple complemented results can be 
obtained in the Cloud Compare program in different formats such as point cloud, 3D surface mesh, orthophoto, and two-dimensional information. Some of the obtained results are shown in figures 5 and 6.

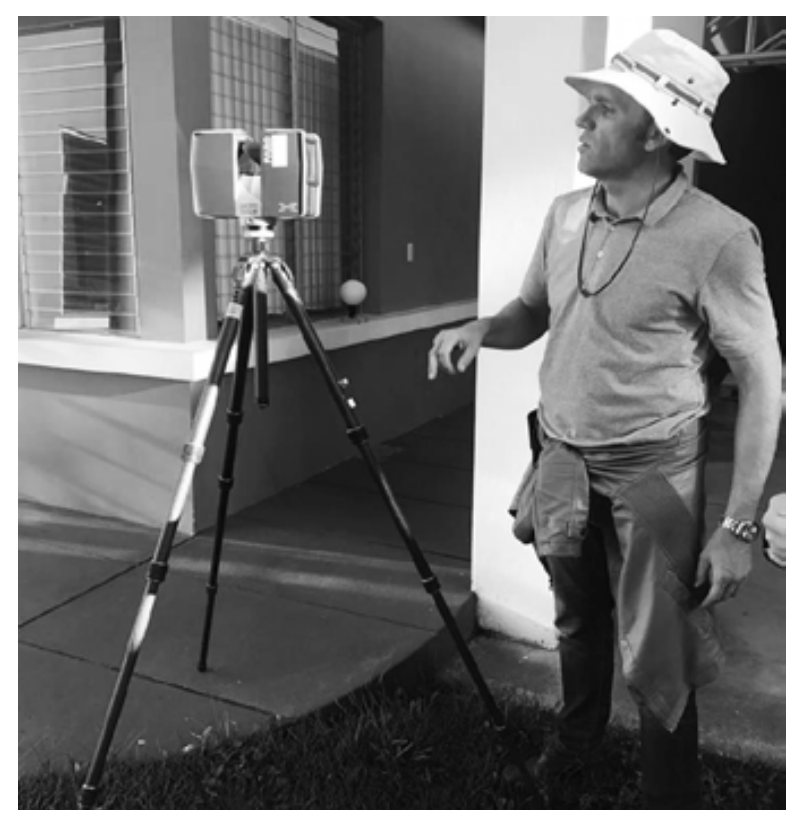

Figure 4: Onsite data collection

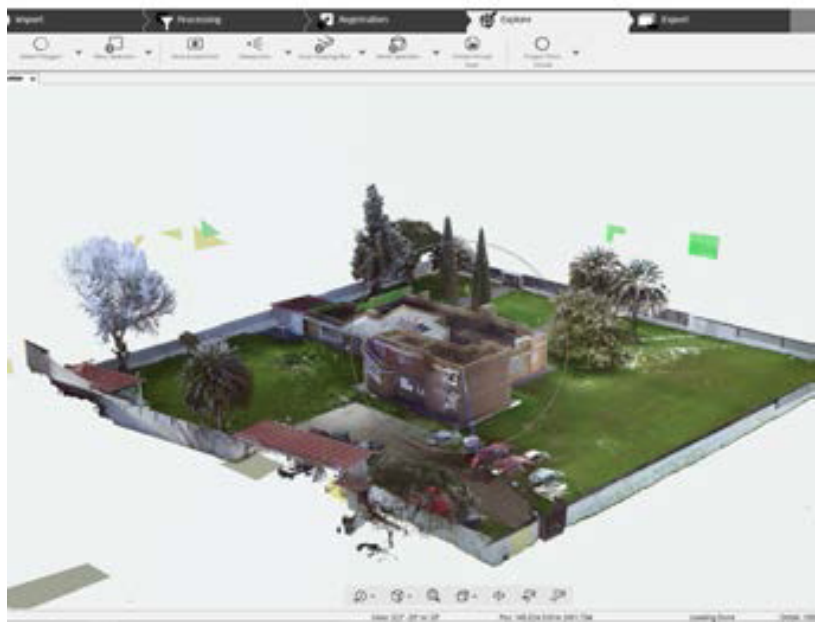

Figure 5: Point cloud of the building surroundings..

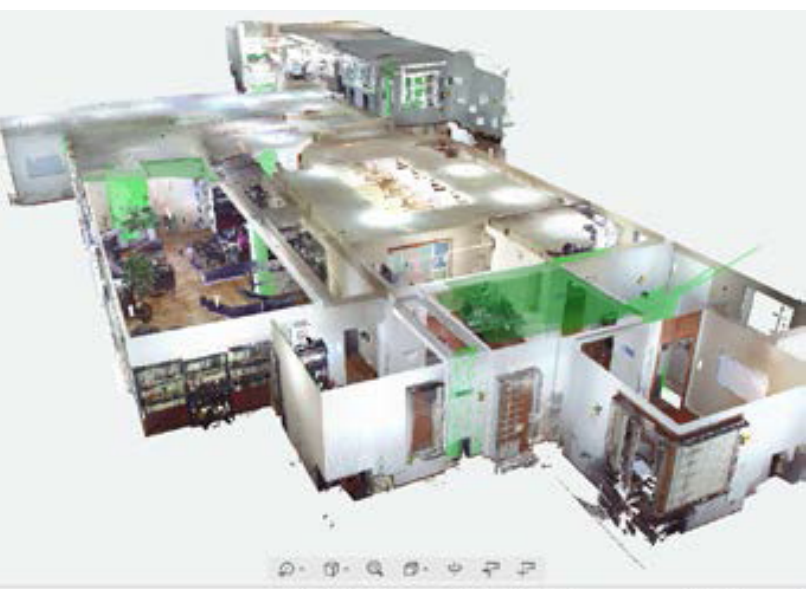

Figure 6: Interior point cloud.

\subsubsection{Photogrammetry}

The photogrammetry was applied to the creation of the cloud of points from the sequential images, in the first place, made by applying the Dji Phantom Drone 4 to capture the upper part and the environment of the building, while for the capture of the facades has been through a Canon EOS Rebel T1i digital camera calibrated with an $18 \mathrm{~mm}$ lens aperture complemented by GPS Spectra Precision mobile mapper 120 that defined the $\mathrm{x}$, $y, z$ coordinates of five edges for the georeference and scale of the point cloud.

Within this research, Agisoft's PhotoScan program is used for the processing and construction of the point cloud, while the results were obtained through Cloud Compare (see figures 7 and 8 ). The error obtained with this digital tool was $+-25 \mathrm{~cm}$, it should be emphasized that the accuracy of the GPS will determine the error in the dimensions of the final model.

The results obtained by this tool are a 3D reconstruction (see figure 9 and 10) that can provide graphic information, orthophotos, a point cloud of the facades in multiple formats, textured meshes, animations and graphics information of the studied set. When the terrain information is available, it increases the possibility to obtain a model of teselas and curves of the level.

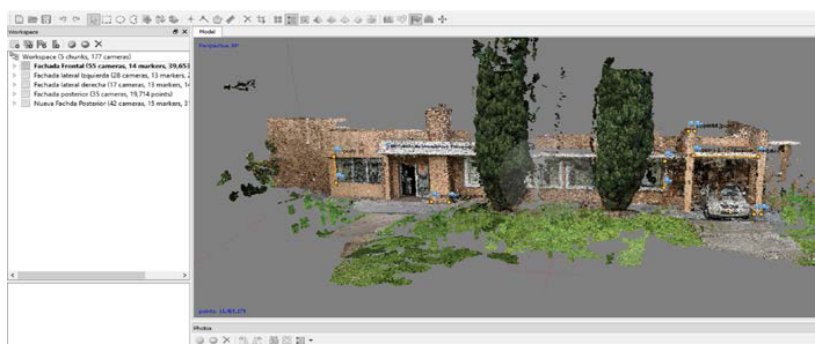

Figure 7: Processing of the exterior point cloud. 


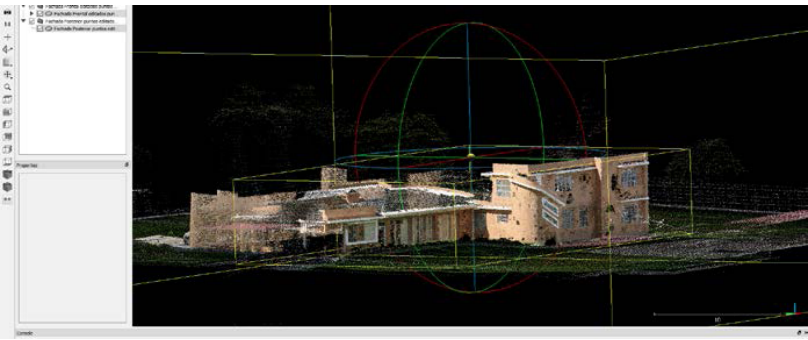

Figure 8: Point cloud made with the photogrammetry obtained data.

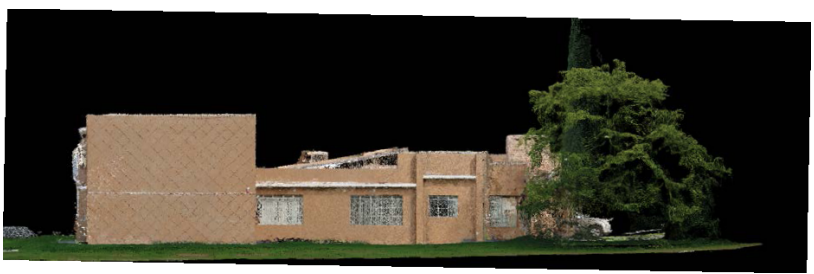

Figure 9: West facade with photogrammetry tool.

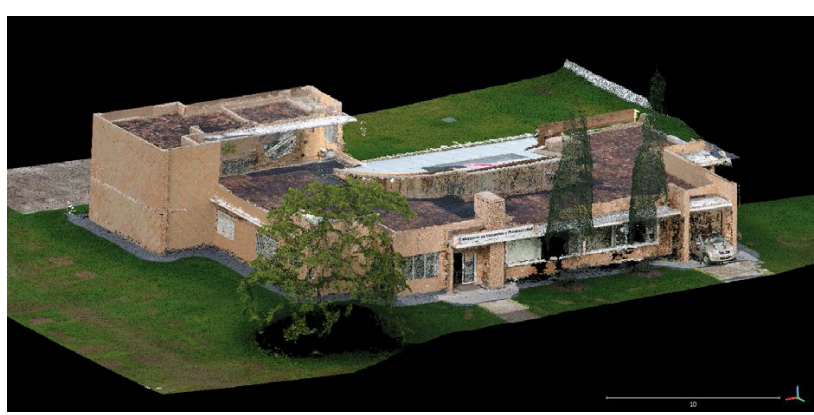

Figure 10: 3D model of "La Casa Peña".

\subsubsection{Rectified Photography}

The rectified photograph is used to obtain two-dimensional information, a Canon EOS Rebel T1i camera stabilized with a tripod was operated to capture images with about $30 \%$ overlap and also a manual measuring instrument to record a horizontal and vertical dimension by each plane allowing to scale the model to the actual size.

For data processing the OnSite Photo program was used, the rectification and scaling of images are made based on the perspective distortion lines to obtain an image on a real scale. For the research aims this program permit to exported to different formats that can be unified or edited for possible interventions, it also offers the possibility of using the CAD format on which the re-drawing can be done. The OnSite Photo program allows the planning of future interventions and extracting a calculation of quantities of work in Excel formats. It is important to mention that even if the described advantages are common and well-known software features, for the ongoing research and the use of point clouds in the city of Cuenca were relevant aspects of the study of modern architecture.

Figure 11 illustrates the drawings made upon the collected data and the image rectification as the main result.

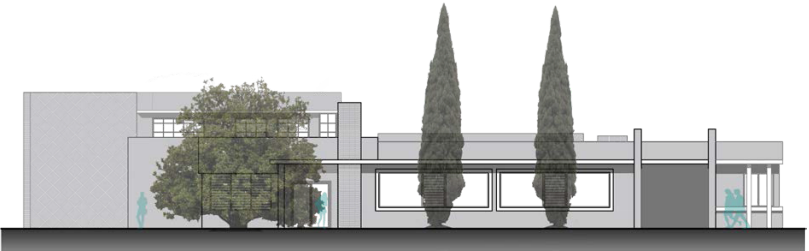

Figure 11: Facade drawing made upon the image rectification.

\section{RESULTS AND DISCUSSION}

The results shown are presented in two main aspects: the development of a documentation fiche for modern architecture in Cuenca and the validation of digital documentation techniques. For the first aspect, the minimum information that must be collected for future identification, validation and value assessment is shown. However, this research will strengthen the process of gathering graphics information for documentation by selecting optimal digital techniques for modern architecture.

\subsection{The documentation fiche for the modern Architecture in Cuenca}

As mentioned in section 2.1, the development of a documentation fiche for modern architecture in Cuenca aims to structure the obtained data from the on-site digital gathering. Consequently, the proposed file includes information such as: identification codes, description of the property, technical aspects, images, graphics information (compiled by the techniques described above), current state of conservation, the INPC states heritage value, author's biography, graphic catalog, location map, bibliography and biography of the author. (See figure 11)

This investigation has covered and validated all the information described above. However, for the objectives of the paper, the graphics information section has been emphasized and at this point, it is worth mentioning that the results extracted by the laser scanner were selected since it was the only technique that allowed to have information inside and with greater accuracy level. However, all selected digital techniques can contribute to the development of a documentation file since the choice of technique will depend mainly on the available resources.

In accordance with the ICOMOS, in order to contribute to the preservation and documentation of twentieth-century architecture, the records must contain information from the inside and outside of the studying building depending on the circumstances, scale drawings, three-dimensional models, photographs and context information. This research verifies and validates the effectiveness of digital techniques for the graphic register of modern architecture, expanding the possibilities of analysis that strengthen the recognition of these assets and their significance over time. 

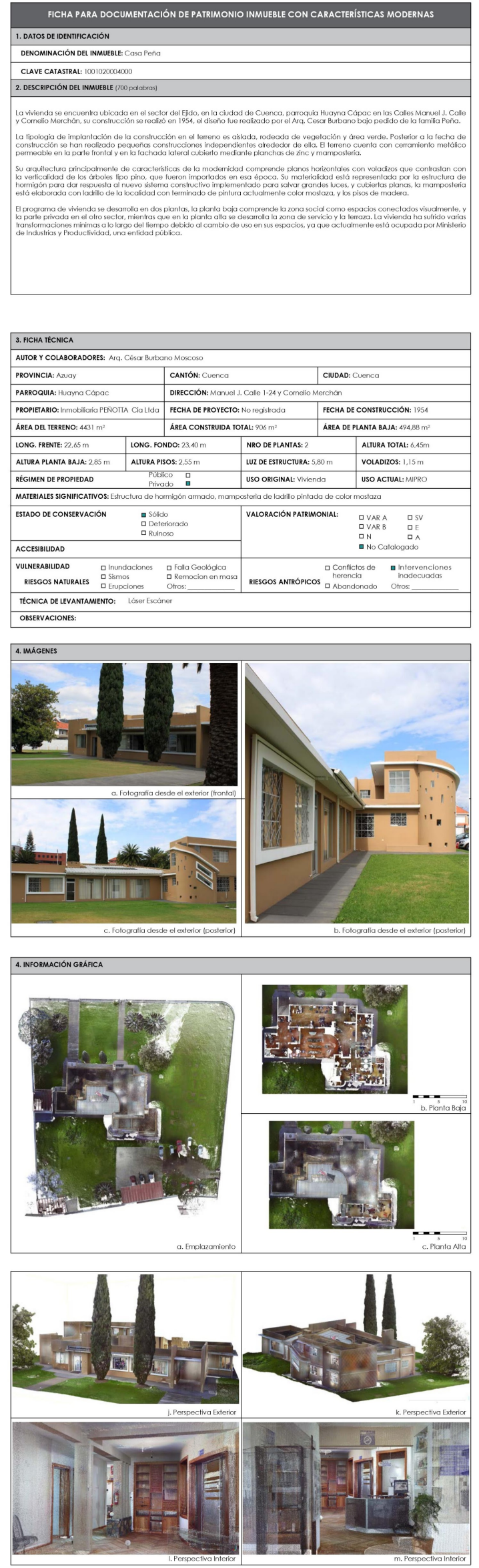
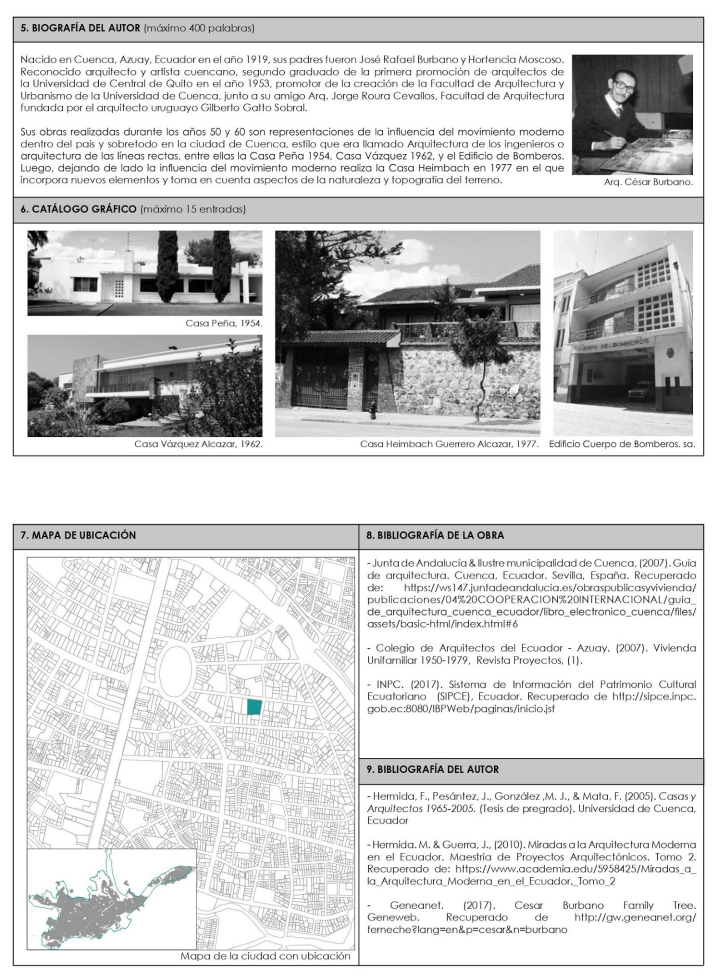

Figure 12: Documentation fiche for modern architecture in Cuenca, application in "La Casa Peña".

\subsection{Evaluation and validation of digital documentation techniques.}

As it was explained before, the application of digital techniques allows obtaining important heritage data, with a high level of precision in less time. Nevertheless, for the selection of a digital documentation technique, one must take into account the balance between the expected results, the desired precision, and the available resources. According to Santana (2003), digital tools have been of great help for the scientific and synthetic analysis of the study of heritage. They also allow results that conventional documentation could not achieve in such a short time.

This research, could determine the application of digital tools in modern architecture and corroborate that it allows the collection of valuable information about tangible elements and points out features for a more precise value assessment. For the city of Cuenca, where a local modern architecture was developed, a mixture of the traditional building principles with the modern movement has been established. Therefore, this research can state that the configuration and constitutive elements of modern architecture can take advantage of the benefits that digital tools offers, however, each of them has restrictions that must be foreseen before their selection.

As shown in Table 1, the results obtained in the application of digital tools for the graphics documentation of modern architecture allows to determine that the laser scanner is the tool with greater precision $\pm 19 \mathrm{~mm}$ and quantity of results, while the results obtained by the photogrammetry, although they are similar, have an error $\pm 25 \mathrm{~mm}$. Finally, rectified photography 
allows for greater accuracy, but its results allow only two-dimensional documentation, which according to the available resources and research needs must be selected and applied.

The results allow future analysis and execution of conservation process that can start from the identification and recognition of valuable features of local modern architecture in Cuenca. In addition, with the use of digital techniques, a comparative analysis of structural elements or transformations can be made over time with a high level of precision.

\begin{tabular}{|c|c|c|c|}
\hline Tool & $\begin{array}{c}\text { Laser } \\
\text { Scanner }\end{array}$ & $\begin{array}{c}\text { Photo/Stereo } \\
\text { grammetry }\end{array}$ & $\begin{array}{c}\text { Image } \\
\text { Rectification }\end{array}$ \\
\hline Occlusion & $\begin{array}{c}\text { rain, } \\
\text { obstacles } \\
\text { night }\end{array}$ & $\begin{array}{l}\text { sun shadow, } \\
\text { rain, } \\
\text { equipment } \\
\text { hits, night }\end{array}$ & rain, night \\
\hline Precision & $\pm 19 \mathrm{~mm}$ & $\pm 25 \mathrm{~cm}$ & $\pm 10 \mathrm{~mm}$ \\
\hline $\begin{array}{l}\text { Equipment } \\
\text { cost }\end{array}$ & high & medium & medium \\
\hline Range & $5-500 m 3$ & $2-100 m 3$ & $2-50 m 3$ \\
\hline $\begin{array}{l}\text { Processing } \\
\text { time }\end{array}$ & 228 hours & 110 hours & 25 hours \\
\hline $\begin{array}{l}\text { Technic } \\
\text { information } \\
\text { results }\end{array}$ & $\begin{array}{c}2 \mathrm{D}, 3 \mathrm{D}, \\
\text { geographic } \\
\text { tools }\end{array}$ & $\begin{array}{c}2 \mathrm{D}, 3 \mathrm{D}, \\
\text { geographic } \\
\text { tools }\end{array}$ & $\begin{array}{l}2 \mathrm{D}, \text { vectorial } \\
\text { tools }\end{array}$ \\
\hline
\end{tabular}

Table 1. Results of the applied documentation tools in the selected case study.

\section{CONCLUSIONS AND RECOMMENDATIONS}

Digital documentation techniques like laser scanner, stereo-photogrammetry, photogrammetry, and rectified photography have shown the possibility to obtain important data with high millimeter precision that could be rapidly obtained. The obtained 3D models allow comparative analysis of the condition, the esthetical, structural aspects of modern structures. For the city of Cuenca, the obtained data should be used for the still required value assessment of this type of local modern architecture.

It is important to mention that even if in some cases the cost of the technical equipment, the invested time in post-production analysis and experts are expensive; the results and the protection that the modern heritage in Cuenca can justify the investment for public institutions. In addition, this research has demonstrated that the combination of different techniques gives better results.

The research emphasizes that the lack of information about local modern architecture reflects no social awareness about the heritage importance of modern architecture in Cuenca. Therefore, it is advisable that all efforts made around the recognition, documentation, and valuation of modern architecture can be promoted within the citizens.
The existing documentation records of local modern architecture in Cuenca, contain limited information related to schematic architectural plans, photographs and ephemeral descriptions about esthetical, technical and historical characteristics. Consequently, the lack of accurate, up-to-date and verified information does not allow a correct conservation process. In addition, this information is not disseminated; therefore, all valuation processes of the modern architecture in Cuenca are annulled.

In accordance with ICOMOS and through different recommendations for documentary archives, the identification and characteristics of the needed information to guarantee the management and dissemination of documentary archives are explained. Based on these documents, the present research has proposed an identification fiche for the documentation of local modern heritage architecture in Cuenca, information that was correlated with digital tools that support the gather the selected data and allows further analysis.

In regard to the evaluated techniques; the scanner laser shows its greater efficiency in terms of the quality of technical, real and visual information. However, if the subsequent analysis will only evaluate formal attributes of a facade; the rectified photograph reveals a millimeter accuracy that could supply the needs of the researcher but, if the subsequent analysis requires information in three dimensions without investing more economic resources; in this case, photogrammetry is the suggested documentation tool.

Therefore, digital documentation techniques have demonstrated the possibility of obtaining important data with a high millimeter precision that could be obtained in less on-site time. The $2 \mathrm{D}$ and $3 \mathrm{D}$ models allow the comparative analysis of the condition, the aesthetic and structural aspects of modern structures. It is important to mention that although in some cases the cost of the technical equipment, the time invested in the analysis and the post-production experts are expensive, the results and the protection of local modern heritage in Cuenca can justify the investment for public institutions. In addition, through this research, the combination of different techniques with better results is an important lesson learned.

The presented results in this research point out the importance of the use, adaptation, and combination of tools for heritage documentation. Public and private institutions are encouraged to create and update digital documentary archives that support the identification, conservation, monitoring and dissemination of all types of built heritage of the World Heritage Site of Cuenca.

The emphasis of the research is the lack of information on local modern architecture. Therefore, it is advisable that all efforts to support the recognition, documentation, and assessment of modern architecture can be promoted between the citizens and managers responsible for heritage conservation.

Finally, from the results presented in this research, the importance of the use, adaptation, and combination of tools for the documentation of local modern heritage. The gathered information should be used as a base for future value assessment. On the other hand, public and private institutions are encouraged to create and update digital documentary archives that support the identification, conservation, monitoring and dissemination of all types of built heritage on the World Heritage Site of Cuenca. 
The International Archives of the Photogrammetry, Remote Sensing and Spatial Information Sciences, Volume XLII-2/W15, 2019 27th CIPA International Symposium "Documenting the past for a better future", 1-5 September 2019, Ávila, Spain

\section{REFERENCES}

Calduch, J., 2009. El declive de la arquitectura moderna: deterioro, obsolencia, ruina. Palapa, IV(II), pp. 29-43.

Colegio de Arquitectos del Ecuador - Azuay. (2007). Vivienda Unifamiliar 1950-1979, Revista Proyectos, (1). Cuenca, Ecuador.

Heras, V., 2009. Development of a Conceptual Model. Heritage Information System, case of study Cuenca-Ecuador. Master Thesis, Catholic University of Leuven, Belgium.

ICOMOS., 1996. Principios para la creación de archivos documentales de monumentos, conjuntos arquitectónicos y sitios históricos. 11a Asamblea General del ICOMOS. Sofía, Bulgaria.

ICOMOS., 2011. Criterios de Conservación del Patrimonio Arquitectónico del Siglo XX. Madrid, España.

INPC., 2017. Sistema de Información del Patrimonio Cultural Ecuatoriano, Ecuador.

http://sipce.inpc.gob.ec:8080/IBPWeb/paginas/inicio.jsf

Muñoz, A.,2009. Arquitectura y Memoria. El Patrimonio Arquitectónico y la Ley de Memoria Histórica. pp. 83-102.

Rovira, T., \& Gastón, C., 2007. El proyecto moderno. Pautas de investigación. Catalonia, Spain.

Santana, M., 2003. The use of three-dimensional techniques of documentation and dissemination in studying built heritage. Catholic University of Leuven, Belgium. 